\title{
ПОТРЕБИТЕЛЬСКИЕ СВОЙСТВА МАРМЕЛАДА С ГРАНАТОВЫМ И СВЕКОЛЬНЫМ СОКОМ
}

\author{
И. Ю. Резниченко, Т. В. Рензяева, Т. Ф. Киселева, А. М. Лебедик
}

\begin{abstract}
Современное развитие кондитерской промышленности связано с решением задач государственной политики в области совершенствования ассортимента кондитерских изделий с позиций удовлетворения потребительского спроса в продуктах «здорового» питания, подбором натуральных ингредиентов, влияющих не только на формирование технологических свойств сырья, но и обладающих высокой биологической ценностью. Разработка и практическая реализация новых видов обогащенных продуктов - наиболее эфрфективный и целесообразный вектор решения поставленных задач. Цель работы - исследование потребительских свойств желейнофрруктового мармелада на основе гранатового и свекольного соков. Объектами исследований являлись образцы мармелада, приготовленные по традиционной и авторским рецептурам. При обосновании выбора сырья для обогащения мармелада учитывали его пищевую, в том числе биологическую ценность, совместимость компонентов и их влияние на органолептические показатели готового продукта. При оценке качества в работе применяли общепринятые методы исследований. Разработанные рецептуры мармелада, отличаются пониженным содержанием сахара и лимонной кислоты. Определены регламентируемые показатели качества нового продукта, рассчитана пищевая иенность. Установлено, что доля белков возросла на 114 \%, содержание пищевых волокон увеличилось на 41-32\%, содержание железа - увеличилось в 71 раз, кальция, в среднем, в 4-8 раз, калия - в 30-40 раз. Состав разработанного фрруктово-желейного мармелада характеризуется наличием витамина $C$, что однозначно повышает пищевую иенность продукта. На новую продукцию составлена техническая документация.
\end{abstract}

Ключевые слова: желейно-фрруктовый мармелад, гранатовый сок, свекольный сок, рецептуры, технология, оценка качества, пищевая ценность.

Тенденция развития рынка мармелада за 2015-2017 годы показала, что традиционный желейный и желейно-фруктовый мармелад пользуется спросом у российских потребителей, однако расширение его ассортимента остается актуальной задачей. Производители предлагают новые виды продукции, в частности: мармелад пониженной энергетической ценности; на фрруктозе; мармелад с «модными» вкусами, например, зеленого чая, мохито, а также изделия с различными наполнителями [1].

Улучшение качества и пищевой ценности кондитерских изделий за счет рационального комбинирования различных видов сырья - наиболее простой и доступный путь оптимизации питания населения. К перспективным направлениям совершенствования ассортимента мармелада, повышения его пищевой и биологической ценности следует отнести применение разнообразного по пищевой ценности и технологическим свойствам природного сырья и полуфабрикатов: овощного и фруктового пюре, пюре шиповника, экстракта облепихового шрота, антоциановых красителей, композиционных настоев лекарственных растений, витаминных и минеральных премиксов и т. д. [2-10].

Целью работы являлось исследование потребительских свойств желейно-фрруктового мармелада, приготовленного с использованием гранатового и свекольного соков. Работа проводилась на кафредре «Управление качеством» ФГБОУ ВО «Кемеровский государственный университет».

В качестве объектов исследования использовались:

- «Мармелад ффигурный», приготовленный по рецептуре № 12 сборника рецептур [11], который служил в качестве контрольного образца (таблица 1);

- модельные образцы формового мармелада с различным соотношением яблочного пюре, свекольного и гранатового сока;

- образцы фрормового мармелада разработанных рецептур: образец, в рецептуру которого входили гранатовый сок, яблочное пюре, сахар кристаллический, агар, кислота лимонная (рецептура № 1) и образец, состав которого содержал сахар кристаллический, яблочное пюре, свекольный сок, гранатовый сок, агар и кислоту лимонную (рецептура № 2). 
При выполнении исследований образцы мармелада готовили из следующего сырья:

- сок гранатовый по ГОСТ 32103-2013;

- caxap кристаллический по ГОСТ 33222-2015;

- яблочное пюре по ГОСТ 32742-2014;

- агар пищевой по ГОСТ 16280-2002;

- свекольный сок по ГОСТ Р 52182-2003.

Определение органолептических и физико-химических показателей мармелада проводили в соответствие с положениями ГОСТ 6442-2014. При оценке качества в работе применяли общепринятые методы исследований.

При разработке рецептур обогащенного мармелада учитывали пищевую и биологическую ценность сырьевых ингредиентов, их влияние на формирование органолептических показателей качества и изменение физико-химических свойств желейно-фрруктового мармелада.

Яблочное пюре, наряду с агаром, является основой для студнеобразования мармелада, но при этом обладает собственной высокой пищевой ценностью. Присутствие пектина в яблочном пюре повышает пищевую ценность мармелада, поскольку он обладает бактерицидными свойствами, нормализует микрофрлору кишечника и улучшает пищеварение. За счет способности к комплексообразованию пектин связывает вредные токсины в организме человека, а затем способствует выведению.

Углеводы яблочного пюре представлены усвояемыми углеводами: фруктозой (7,27 г), глюкозой (5,5 г), мальтозой $(0,9$ г) и сахарозой (1 г), а также пищевыми волокнами в количестве от 1,2 до 1,7г на 100 г. Из витаминов содержатся аскорбиновая кислота (1,7 мг), витамины $\mathrm{B}_{1}, \mathrm{~B}_{2}, \mathrm{~B}_{6}, \mathrm{~B}_{9}$. Из минеральных веществ: калий (75 мг), кальций, магний, натрий, в среднем, по 3 мг/100 г.

Пищевая ценность свекольного сока обусловлена наличием пищевых волокон (2,8 г), витаминов группы В, аскорбиновой кислоты, содержанием кальция, марганца, железа, натрия. Свекольный сок, даже в небольших количествах, способствует выведению токсинов, повышает содержание эритроцитов, стимулирует лимфосистему, относится к продуктам, понижающим содержание холестерина и положительно влияющих на обмен веществ.

Гранатовый сок богат витаминами E, PP, A, C, некоторыми витаминами группы B; минеральными элементами - железом (18 мг), калием (102 мг), кальцием, фосфоором, натрием; органическими кислотами, замени- мыми и незаменимыми аминокислотами, водорастворимыми полифенолами, дубильными веществами. Углеводы гранатового сока (14,2 г) представлены моно- и дисахаридами. Гранатовый сок сохраняет все витамины и полезные вещества, присутствующие в свежем гранате, хорошо усваивается организмом. Гранатовый сок рекомендуется как средство, повышающее уровень гемоглобина в крови, полезен при гипертонии. Полифенолы гранатового сока являются естественными активными антиоксидантами. Танины, пектиновые вещества и фолацин улучшают пищеварение, нормализуют работу желудка, снижают вредное воздействие радиации на организм человека. Благодаря наличию витаминов гранатовый сок укрепляет иммунитет, повышает сопротивляемость инфекционным и простудным заболеваниям.

Модельные образцы мармелада готовили, варьируя в рецептуре дозировки гранатового сока и яблочного пюре (рецептура № 1), гранатового, свекольного соков и яблочного пюре (рецептура № 2), снижая содержание сахара, лимонной кислоты, патоки. Экспериментально установлены оптимальные соотношения гранатового сока и яблочного пюре (15\% и $10 \%$ в рецептуре № 1, соотношение гранатового, свекольного соков и яблочного пюре в рецептуре № 2 составляет $15 \%, 10 \%$ и 8,5\% соответственно. При этом из обеих рецептур исключили патоку.

Разработанные рецептуры мармелада характеризуются отсутствием в составе красителей и ароматизаторов, которые заменяют натуральное сырье, снижением количества сахара на $48 \%$ и лимонной кислоты на $51 \%$. Снижение содержания лимонной кислоты обусловлено тем, что в составе вводимого сока присутствует ряд кислот (яблочная, щавелевая и др.), которые придают свойственный мармеладу привкус. Снижение количества сахара обусловлено наличием собственных сахаров в применяемых обогащающих соках и пюре.

Органолептическую оценку мармелада проводили по 30-балльной шкале, оценивая следующие показатели качества: вкус и запах, цвет, структуру и консистенцию, внешний вид и форму. Образец, набравший от 26 до 30 баллов, соответствовал уровню качества «отлично», 20-25 - «хорошо», 16-19 «удовлетворительно». Результаты оценки органолептических показателей мармелада приведены на рисунке 1.

В таблице 2 приведены органолептические и физико-химические показатели свежевыработанных образцов мармелада. Допол- 
нительно в разработанных образцах мармелада анализировали содержание витамина С.

Пищевая ценность обогащенного мармелада приведена в таблице 3. По сравне- нию с контрольным образцом фрруктовожелейного мармелада, содержание основных пищевых веществ в разработанном мармеладе изменилось.

Таблица 1 - Рецептура контрольного образца желейного мармелада

\begin{tabular}{|c|c|c|c|}
\hline \multirow{2}{*}{ Наименование сырья } & Содержание & \multicolumn{2}{|c|}{ Расход сырья на 1 т готовой продукции, кг } \\
\cline { 3 - 4 } & сухих веществ, \% & в натуре & в сухих веществах \\
\hline Сахар-песок для желе & 99,85 & 511,20 & 510,40 \\
\hline Сахар-песок для обсыпки & 99,85 & 86,60 & 86,50 \\
\hline Патока & 78,0 & 255,50 & 199,30 \\
\hline Сок вишневый натуральный & 10,0 & 200,00 & 20,00 \\
\hline Агар & 85,0 & 10,50 & 8,90 \\
\hline Кислота лимонная & 98,0 & 11,80 & 11,60 \\
\hline Итого & - & 1075,60 & 836,70 \\
\hline Выход & 82,0 & 1000,00 & 820,00 \\
\hline
\end{tabular}
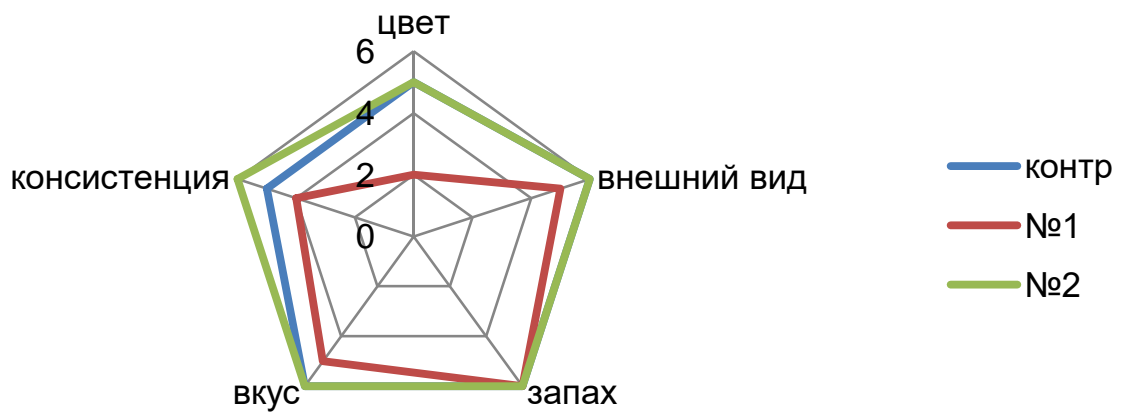

Рисунок 1 - Сравнительная оценка органолептических показателей образцов мармелада

Таблица 2 - Органолептические и физико-химические показатели мармелада

\begin{tabular}{|c|c|c|c|}
\hline \multirow{2}{*}{$\begin{array}{c}\text { Наименование } \\
\text { показателя }\end{array}$} & \multirow{2}{*}{$\begin{array}{c}\text { Требования } \\
\text { ГОСТ6442-2014 }\end{array}$} & \multicolumn{2}{|c|}{ Образец мармелада } \\
\hline & & № 1 & № 2 \\
\hline Вкус и запах & $\begin{array}{c}\text { Характерные для данно- } \\
\text { го наименования, без по- } \\
\text { сторонних привкуса и за- } \\
\text { паха }\end{array}$ & $\begin{array}{c}\text { Вкус яблочный с } \\
\text { нотками граната, без } \\
\text { посторонних привку- } \\
\text { са и запаха. Цвет } \\
\text { коричневый }\end{array}$ & $\begin{array}{c}\text { Вкус сладкий яб- } \\
\text { лочно-гранатовый, } \\
\text { без посторонних } \\
\text { привкуса и запаха. } \\
\text { Цвет гранатовый }\end{array}$ \\
\hline Консистенция & $\begin{array}{c}\text { Студнеобразная, допус- } \\
\text { кается студнеобразная } \\
\text { затяжистая }\end{array}$ & $\begin{array}{l}\text { Студнеобразная, } \\
\text { немного затяжистая }\end{array}$ & $\begin{array}{c}\text { Студнеобразная, не- } \\
\text { много затяжистая }\end{array}$ \\
\hline Форма & $\begin{array}{c}\text { Соответствующая дан- } \\
\text { ному наименованию. Для } \\
\text { формового - правильная, } \\
\text { с четким контуром, без } \\
\text { деформации. } \\
\text { Допускаются незначи- } \\
\text { тельные наплывы }\end{array}$ & $\begin{array}{l}\text { Форма правильная } \\
\text { без деорормаций. } \\
\text { Соответствует фор- } \\
\text { ме, в которую был } \\
\text { отлит мармелад }\end{array}$ & $\begin{array}{c}\text { Форма правильная, } \\
\text { без деформаций. } \\
\text { Соответствует фор- } \\
\text { ме, в которую был } \\
\text { отлит мармелад }\end{array}$ \\
\hline $\begin{array}{l}\text { Массовая доля } \\
\text { влаги ,\% }\end{array}$ & $9-24$ & $18,0 \pm 0,2$ & $16,0 \pm 0,1$ \\
\hline $\begin{array}{l}\text { Общая кислот- } \\
\text { ность, град. }\end{array}$ & $6-22$ & $8,0 \pm 0,1$ & $8,5 \pm 0,1$ \\
\hline $\begin{array}{l}\text { Содержание ас- } \\
\text { корбиновой кис- } \\
\text { лоты, г/100 г }\end{array}$ & Не нормируется & $3,0 \pm 0,1$ & $3,7 \pm 0,1$ \\
\hline
\end{tabular}


Таблица 3 - Пищевая ценность 100 г мармелада

\begin{tabular}{|l|c|c|c|}
\hline \multirow{2}{*}{\multicolumn{1}{c|}{$\begin{array}{c}\text { Наименование } \\
\text { компонента }\end{array}$}} & \multicolumn{3}{|c|}{ образец мармелада } \\
\cline { 2 - 4 } & контрольный & №1 & №2 \\
\hline Белки, г & 0,5 & 0,4 & 0,9 \\
\hline Углеводы, г & 71,0 & 85,0 & 25,0 \\
\hline Пищевые волокна, г & 1,2 & 1,7 & 1,6 \\
\hline Витамин С, мг & 0 & 4,73 & 4,55 \\
\hline Железо, мкг & 0,4 & 28,72 & 28,52 \\
\hline Кальций, мг & 4,0 & 16,78 & 24,28 \\
\hline Калий, мг & 4,0 & 130,0 & 127,75 \\
\hline
\end{tabular}

По сравнению с мармеладом стандартной рецептуры, в мармеладе авторских рецептур доля белков возросла на $114 \%$, содержание пищевых волокон увеличилось на 41-32 \%, содержание железа - увеличилось в 71 раз, кальция, в среднем, в 4-8 раз, калия - в 30-40 раз. Дополнительно следует отметить, что состав разработанного фрруктовожелейного мармелада характеризуется наличием витамина С, что однозначно повышает пищевую ценность нового продукта.

Таким образом, выявлено положительное влияние гранатового, свекольного сока и яблочного пюре на органолептические показатели качества мармелада и увеличение его пищевой и биологической ценности.

Предложенные рецептуры фруктовожелейного мармелада с использованием натурального природного сырья позволяют расширить ассортимент мармелада и повысить его пищевую ценность.

\section{СПИСОК ЛИТЕРАТУРЫ}

1. Анализ спроса и предложения мармеладной продукции в России. Режим доступа http://fb.ru (дата обращения 19.10.2016).

2. Магомедов, Г.О. Желейно-фруктовый мармелад повышенной пищевой ценности с соком из ягод облепихи / Г.О. Магомедов, Л.А. Лобосова, С.Н. Журахова // Техника и технология пищевых производств. - 2017. - Т. 46. - № 3. - С. 50-54.

3. Брашкина, Е.В. Пастило-мармеладные изделия с композиционным структурообразованием / Е.В. Брашкина, М.Ю. Тамова // Кондитерская фрабрика. - 2013. - № 9-10. - С. 49-50.

4. Красина, И.Б. Йодированный мармелад / И.Б. Красина и др. // Кондитерское производство. 2006. - №1. - С. 16.

5. Магомедов, Г.О. Применение агара в производстве мармеладных изделий на основе свежих ягод / Г.О. Магомедов, Л.А. Лобосова, И.Х. Арсанукаев // Хлебопек. - 2012. - № 1. - С. 33-35.

6. Плотникова, Т.В. Потребительские свойства мармелада на основе дикорастущих ягод / Т.В. Плотникова, Е.Б. Табала // Хранение и переработка сельхозсырья. - 2009. - № 4. - С. 69-70.

7. Табаторович, А.Н. Разработка и оценка качества тыквенного мармелада, обогащенного ас- корбиновой кислотой / А.Н. Табаторович, Е.Н.Степанова // Техника и технология пищевых производств. - 2012. - № 4 (27). - С. 57-64.

8. Резниченко, И.Ю. Совершенствование ассортимента кондитерских изделий специализированного назначения / И.Ю. Резниченко, Н.Н. Зоркина, Е.Ю. Егорова // Ползуновский вестник. 2016. - № 2. - C. 4-7.

9. Sagdic, O. Bioactive and rheological properties of rose hip marmalade / O. Sagdic, O.S. Toker, B. Polat, M. Arici, M.T. Yilmaz // Journal of Food Science and Technology. - 2015.- V. 52 (10). - P. 64656474.

10. Егорова, Е.Ю. Комплексная переработка плодово-ягодного сырья: методические подходы / Е.Ю. Егорова // Хранение и переработка сельхозсырья. - 2012. - № 5. - С. 12-15.

11. Иванушко, Л.С. Рецептуры на мармелад, пастилу и зефир: сборник рецептур / Л.С. Иванушко, Г.И. Круглова, И,И. Морозова, А.П. Серик, Е.И. Якубович. - М.: Пищевая промышленность, 1974. 208 c.

Резниченко Ирина Юрьевна, д.т.н., профрессор, зав. кафредрой управления качеством ФГБОУ ВО "Кемеровский государственный университет", 650056, Россия, 2. Кемерово, б-р Строителей, 47, е-mail: reznichenko@gmail.com, тел.: (3842) 39-68-53.

Рензяева Тамара Владимировна, д.m.н., профрессор, профрессор кафедры технологии хлеба, кондитерских и макаронных изделий ФГБОУ ВО "Кемеровский государственный университет", 650056, Россия, 2. Кемерово, б-р Строителей, 47, e-mail: rentamara@mail.ru, тел.: (3842) 39-68-59.

Киселева Татьяна Федоровна, д.т.н., профессор, профессор кафедры технологии бродильных производств и консервирования ФГБОУ ВО "Кемеровский государственный университет", 650056, Россия, г. Кемерово, б-р Cmроителей, 47, e-mail: tf@kemtipp.ru, тел.: (3842) 30-68-55.

Лебедик Анастасия Михайловна, магистрант кафредры управления качеством ФГБОУ ВО "Кемеровский государственный университет", 650056, Россия, г. Кемерово, б-р Строителей, 47, тел.: (3842) 39-68-53. 